\title{
PENERAPAN MODEL PEMBELAJARAN KOOPERATIF TIPE NUMBERED HEADS TOGETHER UNTUK MENINGKATKAN HASIL BELAJAR IPS
}

\author{
Ni Wayan Rati 1,*, Ni Pt. Wiwin Sucidamayanti ${ }^{2}$ \\ 1 Jurusan Pendidikan Guru Sekolah Dasar. Universitas Pendidikan Ganesha, Indonesia \\ 2 Jurusan Pendidikan Guru Sekolah Dasar. Universitas Pendidikan Ganesha, Indonesia
}

\begin{abstract}
Abstrak
Penelitian ini bertujuan untuk mengetahui peningkatan hasil belajar siswa dengan penerapan model pembelajaran (NHT) dalam pembelajaran IPS kelas IV SD No.1 Beratan. Subjek penelitian ini adalah siswa kelas IV semester II SD No. 1 Beratan sebanyak 10 orang siswa, yang terdiri dari 5 orang siswa laki-laki dan 5 orang siswa perempuan. Pengumpulan data dalam penelitian ini menggunakan metode tes. Data yang didapatkan dari metode tes dianalisis dengan metode deskriptif kuantatif. Hasil penelitian menunjukkan adanya peningkatan hasil belajar IPS siswa kelas IV SD No. 1 Beratan. Persentase rata-rata hasil belajar siswa mengalami peningkatan, ini terbukti dari hasil yang diperoleh pada siklus I dengan nilai rata-rata 69,00 dan pada siklus II menjadi 84,50 yang termasuk ke dalam kategori tinggi, sedangkan siswa yang mencapai ketuntasan dari 5 orang siswa menjadi 9 orang siswa dan ketuntasan klasikal pada siklus I sebesar $70 \%$ menjadi $90 \%$ pada siklus II. Dengan demikian penerapan model pembelajaran kooperatif tipe Numbered Heads Together (NHT) dapat meningkatkan hasil belajar siswa kelas IV SD No. 1 Beratan.
\end{abstract}

\author{
Keywords: \\ Model pembelajaran \\ kooperatif tipe \\ Numbered Heads \\ Together, hasil belajar
}

\section{Pendahuluan}

Kualitas kehidupan bangsa sangat ditentukan oleh faktor pendidikan. "Peran pendidikan sangat penting untuk menciptakan kehidupan yang cerdas, damai, terbuka dan demokratis. Oleh karena itu, pembaruan pendidikan harus selalu dilakukan untuk meningkatkan kualitas pendidikan nasional" (Nurhadi, 2004). Dalam konteks pembaruan pendidikan, ada tiga isu utama yang perlu disoroti, yaitu pembaruan kurikulum, peningkatan kualitas pembelajaran dan efektivitas metode pembelajaran. Kurikulum pendidikan harus efektif dan responsif terhadap dinamika sosial, relevan, tidak overload dan mampu mengakomodasikan keberagaman keperluan dan kemajuan teknologi. Kualitas pembelajaran harus ditingkatkan untuk meningkatkan kualitas hasil pendidikan dan secara mikro, harus ditemukan strategi atau pendekatan pembelajaran yang efektif di kelas yang lebih memberdayakan potensi siswa.

Di era pembangunan saat ini, dengan situasi kehidupan yang semakin mengglobal dan kompetitif, sangat dibutuhkan sumber daya manusia Indonesia yang berkualitas tinggi. "Tanpa memiliki kemampuan sumber daya manusia yang tinggi dan mampu bersaing dengan bangsa-bangsa lain di dunia, hanya akan membawa posisi yang tidak atau kurang dapat memanfaatkan situasi yang ada, terutama guna mencapai perbaikan hidup" (Agung, 2010). Untuk itu berbagai pihak sepakat bahwa dunia pendidikan memegang peran utama dalam menyiapkan dan menghasilkan kualitas sumber daya manusia yang tinggi tersebut.

Selama ini hasil pendidikan hanya tampak dari kemampuan siswa menghapal fakta-fakta. Walaupun banyak siswa mampu menyajikan tingkat hafalan yang baik terhadap materi yang diterimanya, tetapi pada kenyataan mereka seringkali tidak memahami secara mendalam substansi materinya. Sebagian besar dari siswa tidak mampu menghubungkan antara apa yang mereka pelajari dengan bagaimana pengetahuan tersebut akan dipergunakan atau dimanfaatkan. Siswa memiliki kesulitan untuk memahami konsep akademik sebagaimana mereka biasa diajarkan yaitu menggunakan sesuatu yang abstrak dan metode ceramah. Mereka sangat butuh untuk memahami konsep-konsep yang berhubungan dengan tempat kerja dan masyarakat pada umumnya dimana mereka hidup dan bekerja (Depdiknas dalam Nurhadi, dkk, 2004).

\footnotetext{
* Corresponding author.

E-mail Addresses niwayan.rati@undiksha.ac.id (Ni Wayan Rati) wiwinputu@yahoo.co.id (Ni Pt. Wiwin Sucidamayanti)
} 
Dewasa ini dibutuhkan strategi belajar yang dapat menghidupkan kelas secara maksimal. Kelas yang hidup diharapkan dapat mengimbangi perubahan yang terjadi di luar sekolah yang demikian cepat. Dengan konsep itu, hasil pembelajaran diharapkan lebih bermakna bagi siswa. Proses pembelajaran berlangsung alamiah dalam bentuk kegiatan siswa bekerja dan mengalami, bukan transfer pengetahuan dari guru ke siswa. Siswa perlu mengerti apa makna belajar, apa manfaatnya dan bagaimana mencapainya. Mereka harus menyadari bahwa yang mereka pelajari berguna bagi hidupnya nanti. Dengan begitu mereka memposisikan sebagai diri sendiri yang memerlukan suatu bekal untuk masa depannya. Mereka mempelajari apa yang bermanfaat bagi dirinya dan berupaya menggapainya (Nurhadi, 2004).

Pendidikan Ilmu Pengetahuan Sosial (IPS) sebagai bagian dari kurikulum sekolah mempunyai peranan besar dalam menyiapkan sumber daya manusia untuk menghadapi kemajuan ilmu pengetahuan dan teknologi. Depdiknas (2005) menyatakan,

Di Indonesia IPS diberikan di sekolah memiliki tujuan mempersiapkan anak didik menjadi warga negara yang baik berdasarkan Pancasila dan UUD 1945, dengan menitik beratkan pada pengembangan individu yang dapat memahami masalah-masalah yang berada dalam lingkungan, baik yang berasal dari lingkungan sosial yang membahas interaksi antar manusia dan lingkungan alam yang membahas interaksi antar manusia dengan lingkungannya, baik sebagai individu maupun sebagai anggota masyarakat, selain itu dapat berpikir kritis dan kreatif dan dapat melanjutkan serta mengembangkan nilai-nilai budaya bangsa.

Kenyataan di lapangan menunjukkan bahwa pembelajaran Ilmu Pengetahuan Sosial (IPS) di sekolah belum mencapai hasil yang diharapkan. Berdasarkan hasil wawancara dengan guru IPS di kelas IV SD No. 1 Beratan dikatakan bahwa penguasaan siswa terhadap materi pelajaran masih tergolong rendah sehingga mengakibatkan rendahnya hasil belajar siswa kelas IV dalam mata pelajaran IPS. Hal ini dapat dilihat juga pada hasil evaluasi penguasaan materi pelajaran IPS siswa kelas IV SD No. 1 Beratan menunjukkan hasil penguasaan materi pelajaran IPS masih rendah, dari hasil belajar IPS siswa kelas IV menunjukkan bahwa 5 orang siswa (50\%) yang sudah memenuhi KKM, sedangkan 5 orang siswa (50\%) yang belum memenuhi KKM, dengan Kriteria Ketuntasan Minimal (KKM) yang telah ditetapkan adalah 60 . Dari data tersebut dapat dinyatakan bahwa hasil belajar IPS masih rendah. Rendahnya hasil belajar IPS siswa juga dipengaruhi oleh berbagai faktor, diantaranya adalah model pembelajaran yang digunakan oleh guru. Hasil observasi awal yang dilakukan oleh peneliti pada SD No. 1 Beratan menunjukan bahwa pembelajaran IPS di sekolah tersebut masih menggunakan model pembelajaran konvensional yakni suatu model pembelajaran yang banyak didominasi oleh guru, sementara siswa duduk secara pasif menerima informasi. Hal ini diduga merupakan salah satu penyebab terhambatnya kreativitas dan kemandirian siswa sehingga menurunkan hasil belajar IPS siswa. Melihat fenomena tersebut, maka perlu diterapkan suatu pembelajaran yang melibatkan peran siswa secara aktif dalam kegiatan belajar mengajar, guna meningkatkan hasil belajar IPS.

Salah satu model pembelajaran yang melibatkan peran siswa secara aktif adalah model pembelajaran kooperatif. Model pembelajaran kooperatif sangat cocok diterapkan pada pembelajaran IPS karena dalam mempelajari IPS tidak cukup hanya mengetahui dan menghafal konsep-konsep IPS tetapi juga dibutuhkan suatu pemahaman serta kemampuan menyelesaikan persoalan IPS dengan baik dan benar. "Melalui model pembelajaran kooperatif akan memberi kesempatan pada siswa untuk bekerja sama dengan sesama siswa dalam tugas-tugas yang terstruktur" (Wena, 2008). Dalam penerapan model pembelajaran kooperatif ini, siswa juga dapat mengemukakan pemikirannya, saling bertukar pendapat dan saling bekerja sama jika ada teman dalam kelompoknya yang mengalami kesulitan.

Maka dalam penelitian ini, model pembelajaran yang dipilih adalah model pembelajaran kooperatif tipe Numbered Heads Together (NHT), karena pada model pembelajaran ini siswa menempati posisi sangat dominan dalam proses pembelajaran dan terjadinya kerjasama dalam kelompok dengan ciri utamanya adanya penomoran sehingga semua siswa berusaha untuk memahami setiap materi pelajaran yang diajarkan dan bertanggung jawab atas nomor anggotanya masing-masing. Dengan pemilihan model ini, diharapkan pembelajaran yang terjadi dapat lebih bermakna dan memberi kesan yang kuat kepada siswa.

\section{Metode}

Sistematis, setelah itu dimasukkan ke dalam suatu Subjek penelitian ini adalah siswa kelas IV SD No. 1 Beratan Kecamatan Buleleng Kabupaten Buleleng pada semester genap tahun pelajaran 2010/2011 dengan jumlah siswa 10 orang (5 siswa perempuan dan 5 siswa laki-laki). Penelitian Tindakan Kelas (PTK) ini dilaksanakan pada siswa kelas IV SD No. 1 Beratan pada semester genap tahun pelajaran 2010/2011. Sekolah ini terletak di Jalan Mayor Metra No. 34A Kecamatan Buleleng Kabupaten Buleleng. 
Sekolah ini dijadikan lokasi penelitian atas pertimbangan sebagai berikut. a) Hasil belajar siswa dalam pembelajaran IPS masih rendah. 2) Guru IPS bersedia berkolaborasi dalam penelitian ini sehingga menunjang pelaksanaan penelitian. 3) Sebagai usaha memperkenalkan pembelajaran kooperatif tipe NHT untuk meningkatkan hasil belajar siswa dalam pembelajaran IPS.

Penelitian tindakan kelas ini dilaksanakan dalam beberapa siklus. Penelitian tindakan kelas terdiri atas rangkaian empat kegiatan yang dilakukan dalam siklus berulang. Tiap siklus terdiri dari empat tahapan yaitu: perencanaan, tindakan, pengamatan dan refleksi. Pelaksanaan penelitian tindakan kelas dimulai dengan siklus pertama yang terdiri dari empat kegiatan. Apabila sudah diketahui letak keberhasilan dan hambatan dari tindakan yang dilaksanakan pada siklus pertama tersebut, maka dilanjutkan dengan menentukan rancangan untuk siklus kedua.

Untuk mengumpulkan data dalam penelitian ini menggunakan metode tes. Dalam penelitian pendidikan yang berkaitan dengan efektivitas program, metode pembelajaran dan kegiatan yang berkaitan dengan kegiatan pembelajaran sering direfleksikan sebagai variabel terikat diantaranya adalah pencapaian hasil belajar. Untuk mengetahui apakah materi yang diberikan oleh seorang guru kepada peserta didik sudah dikuasai mereka, salah satu caranya adalah dengan melakukan pengukuran dengan menggunakan tes. Tes dalam penelitian ini digunakan untuk mengukur hasil belajar IPS siswa kelas IV SD No. 1 Beratan adalah butir-butir tes sesuai dengan pokok bahasan yang telah diberikan.

Setelah data dalam penelitian ini terkumpul maka selanjutnya dilakukan analisis data. Dalam menganalisis data ini menggunakan metode analisis statistik deskriptif kuantitatif dan untuk kualifikasi hasil belajar yang diperoleh siswa menggunakan pedoman konversi. Metode analisis deskriptif kuantitatif merupakan pengolahan data yang penyusunanya itu dilakukan secara objek sehingga penelitian itu dapat disimpulkan. Metode analisis deskriptif kuantitatif ini digunakan untuk menentukan tingkatan tinggi rendahnya hasil belajar IPS yang dikonversikan ke dalam Penilaian Acuan Patokan (PAP) skala lima.

Untuk mengetahui keberhasilan tindakan yang telah dilaksanakan dalam proses pembelajaran yaitu dengan membandingkan hasil penelitian dari siklus I dengan siklus berikutnya. Tingkat keberhasilan pada siklus I dapat diketahui dengan cara membandingkan hasil refleksi awal dan tingkat keberhasilan pada siklus II diperoleh dengan cara membandingkan hasil pada siklus I. Selain itu, keberhasilan tindakan dikatakan mengalami peningkatan apabila telah termasuk dalam kategori sedang dan persentase ketuntasan belajar mencapai $\geq 65 \%$ dan ketuntasan klasikal mencapai $\geq 85 \%$. Apabila kriteria tersebut telah terpenuhi maka penerapan model pembelajaran kooperatif tipe Numbered Heads Together (NHT) untuk meningkatkan hasil belajar IPS siswa kelas IV semester II SD No. 1 Beratan Kecamatan Buleleng Kabupaten Buleleng tahun pelajaran 2010/2011 dianggap berhasil.

\section{Hasil Dan Pembahasan}

Untuk melaksanakan penelitian tindakan kelas ini, peneliti melakukan wawancara dengan guru bidang studi IPS untuk memperoleh gambaran tentang hasil belajar siswa dan juga dilakukan observasi ke kelas untuk mengetahui kegiatan pembelajaran yang dilakukan guru. Sebelum dilakukan siklus I, terlebih dahulu menganalisis data awal yang diperoleh dari hasil pre tes yang dilakukan sebelum proses pembelajaran. Data awal ini dijadikan sebagai bahan untuk melakukan refleksi sebelum mengadakan penelitian. Dari hasil refleksi awal ini akan dijadikan sebagai bahan perbandingan pada siklus I dengan tujuan untuk mengetahui tingkat keberhasilan pada siklus I. Penyebaran ketuntasan pada setiap siswa dapat dilihat pada tabel di bawah ini

Tabel 1 Penyebaran Ketuntasan Setiap Siswa pada Refleksi Awal.

\begin{tabular}{cc}
\hline Rentangan & Frekuensi \\
\hline $90-100$ & 0 \\
$80-89$ & 2 \\
$65-79$ & 3 \\
$55-64$ & 0 \\
$0-54$ & 5 \\
\hline
\end{tabular}

Dari tabel 1, siswa yang dapat dinyatakan tuntas hanya 5 orang siswa karena telah mampu mencapai tingkat ketuntasan $\geq 65$, sedangkan sebanyak 5 orang siswa belum mampu mencapai ketuntasan karena belum mencapai standar atau patokan ketuntasan individual yang dipersyaratkan. Berdasarkan hasil penelitian dari data awal, ketuntasan klasikal diperoleh $50 \%$. Jika dikonversikan ke dalam Pedoman Konversi PAP Skala Lima tentang hasil belajar IPS maka belum dapat dinyatakan tuntas secara klasikal karena belum mencapai ketuntasan $\geq 85 \%$ sesuai dengan indikator yang dipersyaratkan. 
Berdasarkan hasil penelitian siklus I yang diperoleh, penyebaran Ketuntasan pada setiap siswa dapat dilihat pada tabel di bawah ini.

Tabel 2 Penyebaran Ketuntasan Setiap Siswa pada Siklus I

\begin{tabular}{cc}
\hline Rentangan & Frekuensi \\
\hline $90-100$ & 1 \\
$80-89$ & 3 \\
$65-79$ & 1 \\
$55-64$ & 4 \\
$0-54$ & 1 \\
\hline
\end{tabular}

Dari tabel 2, siswa yang dapat dinyatakan tuntas hanya 7 orang siswa karena telah mampu mencapai tingkat ketuntasan $\geq 65$, sedangkan sebanyak 3 orang siswa belum mampu mencapai ketuntasan karena belum mencapai standar atau patokan ketuntasan individual yang dipersyaratkan.

Berdasarkan hasil penelitian dari data awal ini, ketuntasan klasikal diperoleh adalah sebagai berikut.

$$
\begin{aligned}
\text { Ketuntasan Klasikal }= & \frac{\text { Jumlah siswa tuntas }}{\text { Jumlah siswa keseluruhan }} \times 100 \% \\
& =\frac{7}{10} \times 100 \% \\
& =70 \%
\end{aligned}
$$

Berdasarkan hasil penelitian siklus I, ketuntasan klasikal diperoleh 70\%. Jika dikonversikan ke dalam Pedoman Konversi PAP Skala Lima tentang hasil belajar IPS maka belum dapat dinyatakan tuntas secara klasikal karena belum mencapai ketuntasan $\geq 85 \%$ sesuai dengan indikator yang dipersyaratkan. Penelitian tindakan kelas ini dilaksanakan di kelas IV SD No. 1 Beratan, dengan jumlah siswa 10 orang yang terdiri dari 5 orang siswa laki-laki dan 5 orang siswa perempuan. Pada siklus I ini diadakan tiga kali pertemuan. Kegiatan ini dilakukan saat semester genap tahun pelajaran 2010/2011. Pertemuan ke-1 dilaksanakan pada tanggal 12 April 2011, pertemuan ke-2 dilaksanakan pada tanggal 15 April 2011 dan pertemuan ke-3 dilaksanakan pada tanggal 19 April 2011.

pelaksanaan tindakan atau proses pembelajaran, siswa dilengkapi dengan menggunakan Lembar Kerja Siswa (LKS). Setiap pertemuan dalam proses pembelajaran siswa mengerjakan satu LKS dengan kelompoknya masing-masing. Satu kali pertemuan memiliki alokasi waktu 2 jam pelajaran tatap muka selama 70 menit.

Pada kegiatan pembelajaran siklus I terlihat siswa belum terbiasa dengan menggunakan model pembelajarn kooperatif tipe Numbered Heads Together (NHT). Dalam diskusi kelompok masih tampak beberapa siswa saja yang bekerja dalam kelompok. Jika ada guru ataupun peneliti membimbing siswa dalam kelompok, maka siswa pun mau mengerjakan tugas bersama-sama. Setelah selesai mengerjakan Lembar Kerja Siswa (LKS), dilanjutkan dengan penyampaian hasil diskusi. Penomoran yang ada pada masing-masing siswa dalam setiap kelompok, memudahkan siswa untuk mau menyampaikan hasil diskusinya ke depan kelas. Hanya saja siswa yang lain masih kurang berani dalam menanggapi jawaban yang telah disampaikan temannya. Situasi kelas pun terkadang masih gaduh karena ada saja siswa yang berusaha menganggu temannya dalam belajar tapi setelah mendapat teguran, suasana kelas pun kembali tenang

Berkaitan dengan hasil yang diperoleh dari pelaksanaan siklus I, berdasarkan hasil belajar siswa dalam penerapan model pembelajaran kooperatif tipe Numbered Heads Together (NHT) untuk meningkatkan hasil belajar siswa, maka perlu diadakan refleksi karena hasil yang diharapkan belum maksimal. Berdasarkan proses pembelajaran yang telah dilaksanakan maka dapat dibuat refleksi sebagai bahan perbaikan proses pembelajaran pada siklus II. 1) Siswa kurang menghargai pendapat temannya. 2) Siswa kurang aktif menyampaikan pendapat, siswa takut salah menyampaikan pendapatnya. 3) Siswa kurang berani bertanya hal-hal yang mereka belum mengerti. 4) Siswa kurang bekerja sama dalam diskusi kelompok. 5) Hasil diskusi kelompok hanya dikerjakan oleh satu atau dua orang siswa yang pintar. 6) Diskusi kelas hanya didominasi siswa tertentu.

Berdasarkan refleksi yang dilaksanakan pada siklus I, maka pada siklus II dilakukan perbaikan terhadap kekurangan dan kelemahan yang terjadi selama pelaksanaan tindakan. Adapun tindakan tersebut adalah sebagai berikut. 1) Mengingatkan siswa untuk bertanya bila ada hal-hal yang belum dimengerti. 2) Mengingatkan kepada siswa untuk saling menghargai pendapat orang lain. 3) Siswa yang tidak serius dalam mengikuti pembelajaran akan diberikan pertanyaan. 4) Peneliti bersama guru membimbing siswa dalam diskusi kelompok secara bergiliran. 5) Memberikan penghargaan pada siswa yang aktif dalam diskusi kelompok. 6) Memberikan penghargaan pada kelompok yang aktif dalam mengikuti kegiatan pembelajaran. Berdasarkan hasil penelitian siklus II yang diperoleh maka nilai siswa 
dikategorikan tinggi. Karena nilai yang diperoleh bila dikonversikan dengan pedoman penilaian terletak pada rentangan 80-89. Penyebaran Ketuntasan pada setiap siswa dapat dilihat pada tabel di bawah ini.

Tabel 3 Penyebaran Ketuntasan Setiap Siswa pada Siklus II

\begin{tabular}{cc}
\hline Rentangan & Frekuensi \\
\hline $90-100$ & 5 \\
$80-89$ & 2 \\
$65-79$ & 2 \\
$55-64$ & 1 \\
$0-54$ & 0 \\
\hline
\end{tabular}

Dari tabel 3 di atas, siswa yang dapat dinyatakan tuntas sebanyak 9 orang siswa karena telah mampu mencapai tingkat ketuntasan $\geq 65$, sedangkan sebanyak 1 orang siswa belum mampu mencapai ketuntasan karena belum mencapai standar atau patokan ketuntasan individual yang dipersyaratkan.

Berdasarkan hasil penelitian dari data awal ini, ketuntasan klasikal diperoleh adalah sebagai berikut.

$$
\begin{aligned}
\text { Ketuntasan Klasikal } & =\frac{\text { Jumlah siswa tuntas }}{\text { Jumlah siswa keseluruhan }} \times 100 \% \\
& =\frac{9}{10} \times 100 \% \\
=90 \% &
\end{aligned}
$$

Berdasarkan hasil penelitian siklus II, ketuntasan klasikal diperoleh 90\%. Jika dikonversikan ke dalam Pedoman Konversi PAP Skala Lima tentang hasil belajar IPS maka dapat dinyatakan tuntas secara klasikal karena belum mencapai ketuntasan $\geq 85 \%$ sesuai dengan indikator yang dipersyaratkan. Berdasarkan paparan di atas dapat dianalisis bahwa penelitian ini telah berhasil dilaksanakan karena hasil dari siklus I ke siklus II mengalami peningkatan. Dari refleksi awal ke siklus II mengalami peningkatan, baik rata-rata, ketuntasan masing-masing individu maupun ketuntasan secara klasikal. Begitu juga dari siklus I ke siklus II mengalami peningkatan.

Proses pembelajaran pada siklus II ini dilakukan tiga kali pertemuan. Pertemuan ke-1 dilaksanakan pada tanggal 29 April 2011, pertemuan ke-2 dilaksanakan pada tanggal 3 Mei 2011 dan pertemuan ke-3 dilaksanakan pada tanggal 6 Mei 2011. Selama pelaksanaan tindakan atau proses pembelajaran, siswa dilengkapi dengan menggunakan Lembar Kerja Siswa (LKS). Setiap pertemuan dalam proses pembelajaran siswa mengerjakan satu LKS dengan kelompoknya masing-masing. Satu kali pertemuan memiliki alokasi waktu 2 jam pelajaran tatap muka selama 70 menit.

Berkaitan dengan pelaksanaan siklus II, maka guru bersama peneliti berusaha memperbaiki kekurangan atau kelemahan yang terjadi pada kegiatan pembelajaran siklus I. Kegiatan pembelajaran pun semakin kondusif. Siswa semakin antusias dalam mengikuti pembelajaran karena dilengkapi juga media pembelajaran yang menarik perhatian siswa dalam belajar. Siswa pun sudah mau bertanya materi pembelajaran yang belum dimengerti. Dalam diskusi kelompok, terlihat siswa sudah mengetahui bahwa mereka mempunyai tanggung jawab bersama untuk mengerjakan tugas yang diberikan. Siswa juga tampak senang dengan adanya penomoran dalam kelompok dan bahkan ingin nomornya yang ditunjuk agar dapat menyampaikan hasil diskusi mereka.

Refleksi juga dilaksanakan pada akhir siklus II. Pada refleksi siklus II ini, siswa sudah terbiasa dalam bekerja kelompok dan aktif berdiskusi bersama teman kelompoknya, baik itu bertanya, menjawab, mengemukakan pendapat kepada kelompoknya masing-masing maupun kepada guru sehingga terlihat siswa antusias dalam berdiskusi bersama anggota kelompoknya. Selain itu, siswa yang memiliki kemampuan akademik lebih tinggi dalam kelompoknya sudah bisa menghargai pendapat temannya dan membantu temannya yang mempunyai kemampuan akademik yang lebih rendah.

Dengan demikian, melalui interaksi sosial tersebut perbedaan tingkat kemampuan siswa tidak terlihat terlalu mencolok. Walaupun demikian, masih terjadi sedikit kendala-kendala seperti siswa yang masih senang bermain yang mengakibatkan suasana kelas sedikit ribut maupun terjadi selisih pendapat antar anggota kelompok. Namun secara keseluruhan menunjukkan bahwa terjadi peningkatan hasil belajar siswa. Hal ini dikarenakan peneliti mengantisipasi dan memperbaiki kelemahan atau kekurangan dalam kegiatan pembelajaran yang terjadi pada siklus I.

Untuk mengetahui lebih jelas mengenai data siswa dan data perolehan hasil belajar siswa kelas IV SD No. 1 Beratan semester II tahun pelajaran 2010/2011 setelah penerapan model pembelajaran kooperatif tipe Numbered Heads Together (NHT) pada mata pelajaran Ilmu Pengetahuan Sosial (IPS), dapat dilihat pada tabel dan bagan berikut ini. 
Tabel 4 Data Siswa dan Perolehan Nilai Siswa

\begin{tabular}{cccccl}
\hline \multirow{2}{*}{ No. } & \multirow{2}{*}{ Subjek } & \multicolumn{3}{c}{ Nilai Siswa } & \multirow{2}{*}{ Keterangan } \\
\cline { 3 - 5 } & & Refleksi Awal & Siklus I & Siklus II & \\
\hline 1. & $\mathrm{~A}$ & 40 & 55 & 55 & Tidak tuntas \\
2. & $\mathrm{~B}$ & 70 & 80 & 100 & Tuntas \\
3. & $\mathrm{C}$ & 40 & 60 & 70 & Tuntas pada siklus I dan II \\
4. & $\mathrm{D}$ & 80 & 85 & 100 & Tuntas \\
5. & $\mathrm{E}$ & 85 & 90 & 100 & Tuntas \\
6. & $\mathrm{~F}$ & 40 & 55 & 85 & Tuntas pada siklus II \\
7. & $\mathrm{G}$ & 40 & 60 & 85 & Tuntas pada siklus I dan II \\
8. & $\mathrm{H}$ & 70 & 75 & 90 & Tuntas \\
9. & $\mathrm{I}$ & 50 & 50 & 65 & Tuntas pada siklus II \\
10 & $\mathrm{~J}$ & 70 & 80 & 95 & Tuntas \\
\hline \multicolumn{2}{c}{ Jumlah } & 585 & 690 & 845 & Tidak tuntas 1 orang siswa \\
\hline
\end{tabular}

Tabel 5 Profil Hasil Belajar Siswa

\begin{tabular}{ccccc}
\hline \multirow{2}{*}{ Tahapan (Siklus) } & \multicolumn{4}{c}{ Hasil Belajar Siswa } \\
\cline { 2 - 4 } & $\begin{array}{c}\text { Hasil rata-rata } \\
\text { (kualifikasi) }\end{array}$ & Ketuntasan Individual & Ketuntasan \\
\cline { 3 - 4 } & 58,50 & 5 & 5 & $50 \%$ \\
Refleksi Awal & 69,00 & 7 & 3 & $70 \%$ \\
I & 84,50 & 9 & 1 & $90 \%$ \\
\hline II &
\end{tabular}

Tabel 6 Profil Kualifikasi dan Frekuensi Hasil Belajar Siswa

\begin{tabular}{cccccc}
\hline \multirow{2}{*}{ No } & \multirow{2}{*}{ Rentangan } & \multirow{2}{*}{ Kategori } & \multicolumn{3}{c}{ Frekuensi Nilai Siswa } \\
\cline { 4 - 6 } & & & Refleksi Awal & Siklus I & Siklus II \\
\hline 1. & $90-100$ & Sangat tinggi & 0 & 1 & 5 \\
2. & $80-89$ & Tinggi & 2 & 3 & 2 \\
3. & $65-79$ & Sedang & 3 & 1 & 2 \\
4. & $55-64$ & Rendah & 0 & 4 & 1 \\
5. & $0-54$ & Sangat rendah & 5 & 1 & 0 \\
\hline
\end{tabular}

Sejak dilaksanakannya Penelitian Tindakan Kelas (PTK) pada siswa kelas IV SD No. 1 Beratan Kecamatan Buleleng Kabupaten Buleleng, banyak hal yang dapat ditemui terkait dengan kegiatan pembelajaran, mulai dari tahap observasi awal sampai dengan tahap akhir pengambilan data siklus II. Pada saat pertama kali peneliti masuk kelas, peneliti hanya melakukan pengamatan secara langsung terhadap kegiatan pembelajaran yang dilakukan guru. Ketika kegiatan pembelajaran berlangsung terlihat siswa kurang terfokus dalam mengikuti kegiatan pembelajaran. Pada saat kegiatan pembelajaran masih ada siswa yang ribut dan siswa yang tidak antusias dalam menerima pelajaran. Selain itu, masalah lain yang terlihat dalam kegiatan pembelajaran adalah tidak adanya media pembelajaran yang dipergunakan sehingga kurang menarik perhatian siswa dalam mengikuti pembelajaran.

Dari hasil analisis data yang diperoleh dari refleksi awal menunjukkan nilai rata-rata siswa sebesar 58,50. Nilai ini setelah dikonversikan dengan pedoman penilaian termasuk dalam kategori rendah. Siswa yang sudah dianggap tuntas pada refleksi awal ini baru 5 orang siswa atau 50\%, sedangkan yang belum tuntas sebanyak 5 orang siswa atau 50\%. Dilihat dari hasil belajar siswa pada refleksi awal ternyata siswa masih belum optimal dalam penguasaan materi pembelajaran yang telah diberikan oleh guru. Salah satu penyebabnya adalah kurangnya kreativitas siswa dalam mengembangkan diri dan kurangnya kemampuan siswa dalam menerima materi pembelajaran yang diberikan.

Bertolak dari hasil refleksi awal peneliti kemudian menggunakan model pembelajaran kooperatif tipe Numbered Heads Together (NHT). Model pembelajaran ini merupakan salah satu cara yang dilakukan untuk memotivasi siswa dalam kegiatan pembelajaran dengan pemberian nomor pada masing-masing siswa dalam setiap kelompok. Diskusi yang dilakukan adalah usaha untuk membagi informasi sehingga setiap siswa mengetahui jawaban dari permasalahan yang ditugaskan guru. Setelah selesai diskusi kelompok, kemudian guru akan menyebut salah satu nomor tertentu dan para siswa dari tiap kelompok dengan nomor yang sama mengangkat tangan dan menyiapkan jawaban untuk seluruh kelas. Setiap siswa harus siap untuk mewakili kelompok untuk menyampaikan jawaban atau masalah yang menjadi tugasnya. Hal ini tentunya akan lebih membuat siswa untuk memahami materi pembelajaran karena setiap siswa 
memiliki tanggung jawab yang sama untuk menjawab pertanyaan dalam kegiatan diskusi. Dalam model pembelajaran ini, siswa akan dapat melatih dirinya untuk mengemukakan pendapat dan mendorong siswa untuk meningkatkan semangat kerjasama mereka.

Selain itu, model pembelajaran kooperatif tipe Numbered Heads Together (NHT) memberikan kesempatan pada siswa untuk bekerjasama dengan teman kelompoknya, berinteraksi sosial dan membagi ide-ide serta mempertimbangkan jawaban yang paling tepat dari hasil interaksinya tersebut. Melalui model pembelajaran ini, siswa belajar melaksanakan tanggung jawab pribadi dan kelompoknya serta saling keterkaitan dengan anggota kelompok. Model pembelajaran kooperatif tipe Numbered Heads Together (NHT) memberikan gambaran pada siswa mengenai kenyataan kehidupan di masyarakat yaitu dalam hidup bermasyarakat diperlukan hubungan ketergantungan dan interaksi sosial antara individu dengan individu lain, antara individu dengan kelompok serta antara kelompok dalam masyarakat.

Pada siklus I, hasil belajar yang diperoleh cukup memuaskan karena adanya peningkatan hasil belajar siswa. Dari hasil penelitian pada siklus I, didapatkan nilai rata-rata siswa sebesar 69,00. Jika dibandingkan dengan hasil dari rata-rata awal terdapat peningkatan dari 58,50 menjadi 69,00 atau meningkat sebesar 10,5. Jumlah siswa yang berhasil mencapai tingkat ketuntasan juga bertambah dari 5 orang siswa menjadi 7 orang siswa. Sedangkan yang tidak tuntas mengalami penurunan dari 5 orang siswa menjadi 3 orang siswa. Pada siklus I ketuntasan klasikalnya sebesar 70\%. Jumlah ini mengalami peningkatan jika dibandingkan dengan data awal sebesar 50\%. Berarti ketuntasan klasikalnya telah meningkat sebasar 20\%. Walaupun secara klasikal belum dapat dinyatakan tuntas tetapi secara kuantitatif terlihat adanya peningkatan hasil belajar siswa setelah diterapkan model pembelajaran kooperatif tipe Numbered Heads Together (NHT). Hasil yang diperoleh pada siklus I ini tentu saja belum memenuhi target yang diharapkan karena nilai rata-rata siswa masih dalam kategori sedang. Untuk itu, perlu diadakan perbaikan dalam pelaksanaan pembelajaran yang sesuai dengan kekurangan maupun kendala-kendala yang ditemukan pada pelaksanaan pembelajaran siklus I.

Dilihat dari hasil refleksi terhadap pelaksanaan tindakan siklus I, terlihat adanya kekurangan maupun kendala-kendala yang muncul dalam proses pelaksanaannya. Kendala-kendala tersebut disebabkan oleh beberapa hal antara lain siswa belum terbiasa berdiskusi dalam menyelesaikan tugas yang diberikan. Hal ini disebabkan oleh kebiasaan siswa yang hanya pendengar dan pencatat selama kegiatan pembelajaran, siswa belum terbiasa dalam melaksanakan diskusi, siswa masih malu untuk bertanya, siswa masih memiliki sifat egosentris dan merasa dirinya lebih baik dari temannya, tidak semua siswa turut aktif dalam mengerjakan tugas yang diberikan dan mereka cenderung hanya mengandalkan seorang temannya untuk mengerjakan tugas tersebut dan siswa belum terbiasa dalam membuat simpulan yang sistematis sehingga siswa masih membutuhkan bantuan guru dalam membuat simpulan.

Bertolak dari kekurangan-kekurangan yang dihadapi pada siklus I, peneliti bersama guru mendiskusikan perbaikan tindakan untuk selanjutnya diterapkan pada siklus II. Perbaikan tindakan yang dilakukan antara lain memberikan motivasi kepada siswa untuk selalu bekerjasama dalam kelompoknya masing-masing, memberikan arahan pada siswa yang masih mengganggu temannya, mengarahkan siswa dalam membuat simpulan dengan memberikan pertanyaan-pertanyaan yang mengarah pada simpulan yang diharapkan. Dalam diskusi kelas, setiap siswa juga diberikan kesempatan untuk menanggapi simpulan temannya.

Berdasarkan implementasi rancangan pada siklus II yang merupakan perbaikan tindakan pada siklus I, memberikan peningkatan hasil yang signifikan. Pada siklus II ini, peneliti berusaha memperbaiki kekurangan-kekurangan yang ditemui pada siklus I. Setelah diperoleh data pada siklus II, nilai rata-rata yang diperoleh siswa sebesar 84,50 sedangkan nilai rata-rata 69,00. Ini berarti terjadi peningkatan nilai rata-rata siswa dari siklus I dengan siklus II yaitu sebesar 15,5. Siklus II memperoleh hasil yang lebih baik dibandingkan siklus I. Keberhasilan ketuntasan belajar siswa ini, meningkat dari 7 orang siswa menjadi 9 orang siswa. Sedangkan siswa yang belum tuntas mengalami penurunan dari 3 orang siswa pada siklus I menjadi 1 orang siswa pada siklus II. Pada siklus II, ketuntasan klasikalnya juga mengalami peningkatan dari 70\% menjadi 90\%. Ini berarti terjadi peningkatan ketuntasan klasikal sebesar 20\%. Dari perhitungan ketuntasan klasikal yang diperoleh pada siklus II, dapat dinyatakan sudah mencapai ketuntasan karena sudah mencapai nilai lebih dari $85 \%$.

Terjadinya peningkatan hasil belajar IPS siswa dikarenakan siswa sudah terbiasa dengan model pembelajaran kooperatif tipe Numbered Heads Together (NHT) dan sebagian besar siswa telah serius dalam diskusi kelompok sehingga diskusi kelompok dapat berjalan dengan lancar.

Secara umum, pada pelaksanaan tindakan siklus II tidak lagi muncul kendala-kendala seperti pada siklus I. Siswa sudah terbiasa dan telah terlatih belajar dengan mengikuti penerapan model pembelajaran kooperatif tipe Numbered Heads Together (NHT). Hal ini terlihat dari kegiatan yang dilakukan siswa telah menunjukkan keterampilan sosial yang diharapkan seperti siswa sudah antusias dalam mengikuti pembelajaran yang dilaksanakan, siswa sudah saling membantu antar anggota 
kelompok, siswa serius dalam diskusi kelompok, siswa sudah berani mengajukan pertanyaan, mengemukakan pendapat dan menanggapi jawaban temannya. Dengan tercapainya keterampilan sosial seperti yang telah disebutkan di atas, tentunya hal ini menyebabkan hasil belajar IPS siswa meningkat dari siklus sebelumnya. Walaupun salah satu siswa masih berada dalam kategori kurang, hal ini dikarenakan siswa tersebut kurang tanggap dalam menerima pelajaran sehingga siswa tersebut mengalami kesulitan dalam mengerjakan soal-soal individu yang berdampak pada hasil belajar siswa tersebut kurang maksimal.

Penelitian tindakan kelas ini juga pernah dilakukan oleh Mahardiyasa (2010) yang menerapkan model pembelajaran kooperatif tipe Numbered Heads Together (NHT) untuk meningkatkan hasil belajar matematika siswa kelas V. Hasil penelitian yang dilakukan menunjukkan peningkatan siklus I sebesar 63,91 dan pada siklus II rata-rata kelas sebesar 72,08. Artinya penelitian ini berhasil karena telah mencapai ketentuan klasikal diatas $85 \%$.

Dari paparan di atas, secara umum telah mampu menjawab rumusan masalah. Penelitian ini dapat dikatakan berhasil, karena semua kriteria yang ditetapkan telah terpenuhi. Jadi, dapat dinyatakan bahwa penerapan model pembelajaran kooperatif tipe Numbered Heads Together (NHT) dapat meningkatkan hasil belajar IPS siswa kelas IV Semester II SD No. 1 Beratan Kecamatan Buleleng Kabupaten Buleleng tahun pelajaran 2010/2011.

\section{Simpulan Dan Saran}

Berdasarkan rumusan masalah di atas, maka dapat disimpulkan bahwa penerapan model pembelajaran kooperatif tipe Numbered Heads Together (NHT) dapat meningkatkan hasil belajar IPS siswa kelas IV semester II SD No. 1 Beratan tahun pelajaran 2010/2011. Ini terbukti dari hasil yang diperoleh pada siklus I dengan nilai rata-rata 69,00 dan pada siklus II menjadi 84,50 dan siswa yang mencapai ketuntasan dari 5 orang menjadi 9 orang. Sedangkan ketuntasan klasikalnya pada siklus I sebesar $70 \%$ menjadi $90 \%$ pada siklus II.

Berdasarkan hasil penelitian ini, disampaikan beberapa saran antara lain. 1) Kepada siswa agar dapat aktif dalam mengikuti kegiatan pembelajaran dan tidak malu untuk bertanya jika ada materi pembelajaran yang belum dimengerti. 2) Kepada guru IPS agar dapat menerapkan model pembelajaran kooperatif tipe Numbered Heads Together (NHT) dengan mempertimbangkan beberapa hal seperti model pembelajaran ini dapat melatih siswa dalam mengemukakan pendapat maupun memotivasi siswa untuk mengembangkan kemampuan dirinya. 3) Kepada sekolah agar dapat menjadikan model pembelajaran kooperatif tipe Numbered Heads Together (NHT) sebagai salah satu alternatif untuk meningkatkan hasil belajar siswa. 4) Kepada pembaca atau peneliti lain yang berminat untuk mengadakan penelitian lebih lanjut mengenai model pembelajaran kooperatif tipe Numbered Heads Together (NHT) pada mata pelajaran IPS maupun pada mata pelajaran lainnya yang sesuai agar dapat memperhatikan kendalakendala yang peneliti hadapi sebagai bahan pertimbangan untuk dapat memberikan kontribusi hasil yang lebih optimal.

\section{Daftar Pustaka}

Agung, A. A. Gede. 2005. Metodologi Penelitian Pendidikan. Singaraja: IKIP Singaraja.

Agung, Iskandar. 2010. Meningkatkan Kreativitas Pembelajaran Bagi Guru Pedoman Acuan Guru dalam Meningkatkan Kreativitas Pembelajaran pada Peserta Didik. Jakarta: Penerbit Bestari Buana Murni.

Arikunto, Suharsimi. 1997. Prosedur Penelitian Suatu Pendekatan Praktek Edisi Revisi V. Jakarta: PT Rineka Cipta.

-----, dkk. 2010. Penelitian Tindakan Kelas. Jakarta: PT Bumi Aksara.

Asy'ari, dkk. 2007. Ilmu Pengetahuan Sosial SD Untuk Kelas IV. Jakarta: Erlangga.

Depdiknas. 2005. Materi Pelatihan Terintegrasi Ilmu Pengetahuan Sosial. Jakarta: Depdiknas Direktorat Jenderal Pendidikan Dasar dan Menengah Direktorat Pendidikan Lanjutan Pertama.

Dzaki, Muhammad Faiq.2009. Ciri Model Pembelajaran Kooperatif. Tersedia pada http://penelitiantindakankelas.bspot.com/2009/03/ciri-model-pembelajaran-kooperatif.html (diakses tanggal 9 Maret 2010).

Dimyati dan Mudjiono. 2009. Belajar dan Pembelajaran. Jakarta: Rineka Cipta. 
Harminingsih. 2008. Faktor-faktor yang Mempengaruhi Hasil Belajar. Tersedia pada http://harminingsih.blogspot.com/2008/08/faktor-faktor-yang-mempengaruhi-hasil.html (diakses pada tanggal 19 Pebruari 2011).

Hisnu P, Tantya dan Winardi. 2008. Ilmu Pengetahuan Sosial SD Untuk SD/MI Kelas 4. Jakarta: Pusat Perbukuan Departemen Pendidikan Nasional.

Ibrahim, dkk. 2000. Pembelajaran Kooperatif. Surabaya: Universitas Negeri Surabaya: University Press.

Isjoni, H. 2009. Pembelajaran Kooperatif Meningkatkan Kecerdasan Komunikasi Antar Peserta Didik. Yogyakarta: Pustaka Pelajar.

Jihad, Asep dan Haris, Abdul. 2008. Evaluasi Pembelajaran. Yogyakarta: Multi Pressindo.

Mahardiyasa, Putu. 2010. Penerapan Model Pembelajaran Kooperatif Tipe NHT Untuk Meningkatkan Hasil Belajar Matematika Siswa Kelas V SD No. 3 Banjar Tegal Tahun Pelajaran 2009/2010. Skripsi (tidak diterbitkan). Jurusan Pendidikan Guru Sekolah Dasar, Fakultas Ilmu Pendidikan, Universitas Pendidikan Ganesha Singaraja.

Muhammad. 2010. Pembelajaran IPS di Sekolah Dasar. Tersedia pada http://portal2.lpmpkalsel.org/index.php?option=com content\&view=article\&id=6:pipssd\&catid= 8:catipop\&Itemid=7 (diakses pada tanggal 13 Oktober 2010).

Mulyasa, E. 2002. Kurikulum Berbasis Kompetensi Konsep, Karakteristik dan Implementasi. Bandung: PT Remaja Rosdakarya.

Munawar, Indra. 2009. Hasil-Hasil yang Mempengaruhi Hasil Belajar. Tersedia pada http://indramunawar.blogspot.com/2009/06/faktor-faktor-yang mempengaruhi-hasil.html (diakses pada tanggal 19 Pebruari 2011).

Nurhadi. 2004. Kurikulum 2004 Pertanyaan dan Jawaban. Jakarta: PT Gramedia Widiasarana Indonesia.

Nurhadi, dkk. 2004. Pembelajaran Kontekstual dan Penerapannya dalam KBK. Malang: Penerbit Universitas Negeri Malang.

Nurkancana dan Sumartana. 1986. Evaluasi Pendidikan. Surabaya: Usaha Nasional.

Prayitno, Baskoro Adi. 2010. Potensi Pembelajaran Kooperatif dalam Memberdayakan Prestasi Belajar Siswa Under Achievment. Tersedia http://baskoro1.blogspot.com/2010/08/potensipembelajaran-kooperatif-dalam.html (diakses pada tanggal 19 Pebruari 2011).

Riyanto, Yatim. 2001. Metodologi Penelitian Pendidikan. Surabaya: Penerbit SIC.

-----. 2009. Paradigma Baru Pembelajaran Sebagai Referensi bagi Pendidik dalam Implementasi Pembelajaran yang Efektif dan Berkualitas. Jakarta: Kencana Prenada Media Group.

Sadiman, I.S dan Amalia, Shendy. 2008. Ilmu Pengetahuan Sosial SD/MI Kelas IV. Jakarta: Pusat Perbukuan Departemen Pendidikan Nasional.

Solihatin, Etin dan Raharjo. 2009. Cooperative Learning Analisis Model Pembelajaran IPS. Jakarta: Bumi Aksara.

Sudjana, Nana. 1987. Dasar-Dasar Proses Belajar Mengajar. Bandung: Sinar Baru Algensindo.

Surapranata, Sumarna. 2004. Panduan Penulisan Tes Tertulis Implementasi Kurikulum 2004. Bandung: PT Remaja Rosdakarya.

Syah, Muhhibin. 1995. Psikologi Pendidikan dengan Pendekatan Baru. Bandung: PT Remaja Rosdakarya.

Trianto. 2009. Mendesain Model Pembelajaran Inovatif-Progresif Konsep, Lamdasan dan Implementasinya pada Kurikulum Tingkat Satuan Pendidikan (KTSP). Jakarta: Kencana Prenada Media Group.

Umar, Arsyad, dkk. 2004. Pengetahuan Sosial Terpadu Jilid 4 Untuk Kelas 4. Jakarta: Erlangga.

Wena, Made. 2010. Strategi Pembelajaran Inovatif Kontemporer Suatu Tinjauan Konseptual Operasional. Jakarta: Bumi Aksara. 
Yasa, Doantara. 2008. Metode Pembelajaran Kooperatif. Tersedia pada http://ipotes.wordpress.com/2008/05/10/metode-pembelajaran-kooperatif/ (diakses tanggal 22 Januari 2011). 